\section{Grazing History of the Northwest ${ }^{1}$}

\section{WILLIAM A. GALBRATTH AND E. WILLIAM ANDERSON}

Power Marketing Specialist, Bonneville Power Administration; and State Range Specialist, Soil Conservation Service, Portland, Oregon.

\section{Highlight}

The earliest grazing in the Northwest (which probably began about 1700) was by Indian horses. Livestock-a few head of cattle-were first brought to the Northwest at Nootka Bay on Vancouver Island, B.C., by Spaniards in 1789. By 1825, there were 27 head of cattle at Vancouver, Wash., near the mouth of the Columbia River. Marcus Whitman brought cattle to the area east of the Cascade Mountains in 1836. Mass movements of cattle took place from western Oregon to east of the Cascades during the 1860's. Numbers skyrocketed which resulted in sizeable exportations of livestock in the late 1800 's to regions east of the Rocky Mountains, largely for building base herds. These drives contributed significantly to development of the livestock industry east of the Rockies, although they have been largely neglected by writers who chose, rather, to popularize the cattle drives from Texas and the Southwest.

Raising livestock on rangeland is still, and will continue to be, one of the major basic industries in the Pacific Northwest. There are many millions of acres of private and public rangeland and grazable woodland in the Pacific Northwest on which concurrent grazing by livestock and game should continue to be one of the major uses of the resource.

The history of grazing seems to have followed a similar pattern throughout the world. First, an abundance of native forage-one of

\footnotetext{
${ }^{1}$ Received September 27, 1969; ac-
} cepted for publication June 8, 1970 . the greatest natural resources available to man-then deterioration or loss of that resource, followed by efforts for rehabilitation. This paper summarizes the grazing history of Oregon, Washington, and British
Columbia. The history of grazing in this region is a very large part of the history of the people who developed the region.

In 1805 when Lewis and Clark reached the mouth of the Columbia River, completing their journey of exploration, the Northwest was a vast land untouched and unexploited by civilization. The natural resources were mainly timber, minerals, water, and land. But before any of these could be developed and made to serve mankind, people had to be able to live from the land. An all-important resource, namely grass, made this possible. Here was a resource immediately necessary and immediately available.

In the early history of the Northwest, cattle supplied several basic needs of people. Beef and milk were basic foods. Cattle also supplied fat and cheese. They were used as draft animals to supply power for plowing, to pull wagons and other implements; and hides provided leather for many purposes. People even made use of cattle hoofs and horns. Cattle, 


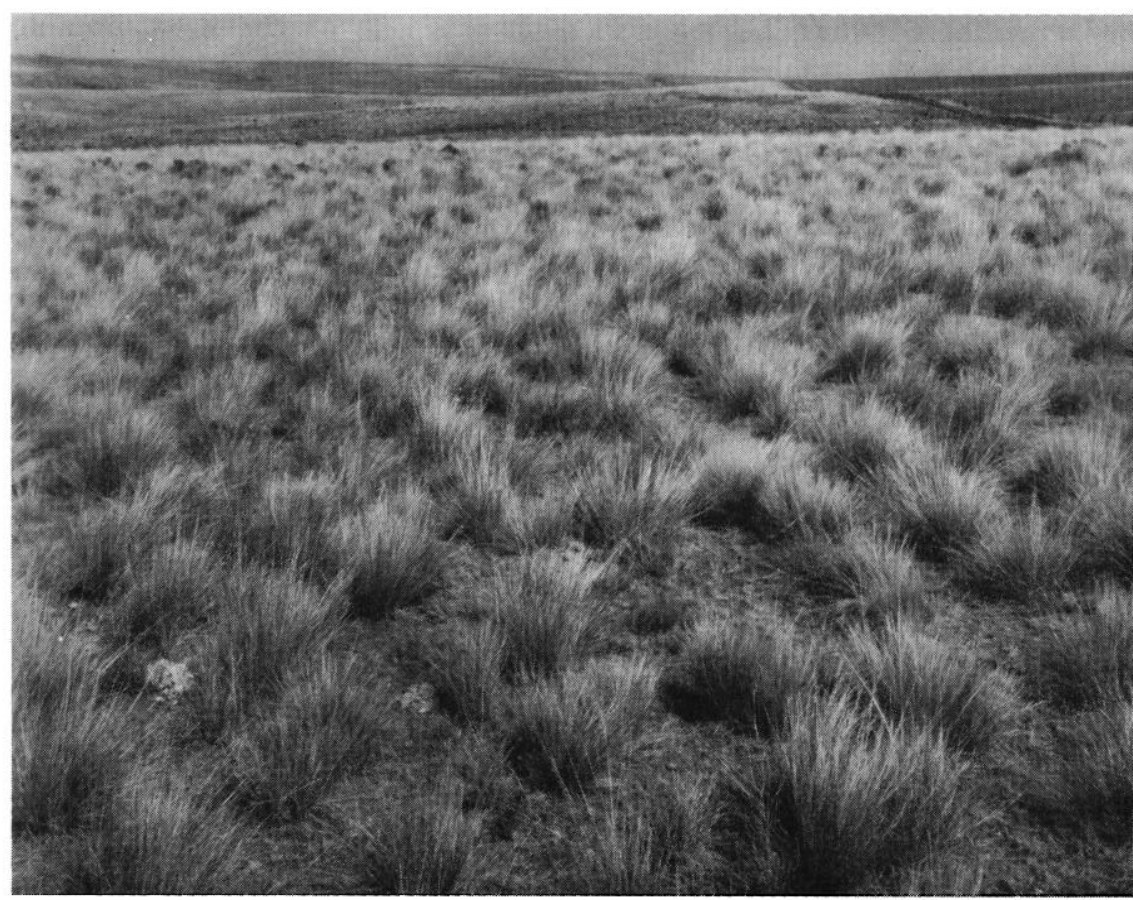

FIG. 1. The bunchgrass range of the Pacific Northwest. (Soil Conservation Service photo)

sheep, and horses all depended upon grass for their sustenance.

In the early 1800 's, this vast region produced some of the finest grassland in the world (Fig. 1). Component species collectively were called bunchgrass. Three major species were prominent in this vast sea of grass which lay east of the Cascade Mountains. These are bluebunch wheatgrass (Agropyron spicatum Pursh.), Idaho fescue (Festuca idahoensis Elmer.) and Sandberg bluegrass (Poa secunda Presl.). The larger grasses grew 18 to 36 inches tall and, either green or dry, were excellent forage for livestock. In the valleys, on the hills and on the plains, these grasses extended like endless seas. Along with this seemingly unlimited supply of food for livestock was also an abundance of water. Much of the water was poorly distributed, but over-all, few places in the world had ever been endowed so lavishly with this essential resource.

Indians were making some use of the grass. In a Shoshone village, Lewis and Clark saw 700 horses. They estimated that there were thousands more in the hills. These were descendants of Spanish horses from the Southwest. It is believed that the Shoshone Indians acquired their first horses between 1690 and 1700 from a Spanish mission at Santa Fe, N. Mexico (Haines, 1938). By 1730 , horses probably ranged in the Snake River Valley of southern Idaho and throughout parts of eastern Oregon and Washington. When the first white men came, these horses along with game, mostly deer and elk, were the only consumers of native foreage. Very few buffalo moved into the Pacific Northwest region. A few sometimes entered the Snake River Valley, and some may have moved as far west as Wenatchee, Wash.; but they were never a factor in grass consumption in the Northwest.

Probably unknown to Lewis and Clark when they reached the Pacific Ocean in 1805, was the fact that 16 years before (in 1789) the Spaniards had brought a few head of cattle to their settlement at Nootka Bay on Vancouver Island, B.C., some 400 miles to the north. These cattle had been brought by sailing vessel from the Hawaiian Islands. In 1792 , three or four head of cattle were moved across the strait to Neah Bay, Washington. These were the first known cattle in the Northwest.

By 1825 cattle were beginning to be a factor in the economic life of certain isolated areas. By that time, there were 27 head at Vancouver near the mouth of the Columbia River. The following year in what is now eastern Washington there were a few cattle in Okanogan Valley and 3 young cows at Fort Colville.

Marcus Whitman brought several head of cattle across the country to Walla Walla Valley, Washington, in 1836. By this time people in the little settlements throughout the Northwest were recognizing the importance of cattle and sheep and that there was food in abundance for such livestock. The first recorded kill of cattle specifically for beef was at Vancouver, Washington, in 1836. Up to this time, cattle were kept to produce milk and cheese and to increase in numbers.

By the middle 1830's, Oregon Territory was being recognized as a land of opportunity. More and more the word was being spread throughout the East that here was a land from the west slope of the Rockies to the Pacific Ocean where grass was never ending, where water was in abundance, and where timber was available for cabins and other buildings, all free to men with the courage to take it. Moreover, it was accepted as a fact that the climate was such that livestock could live on the open range throughout the winter and thrive. Even in the face of early experiences to the contrary, this theory was believed, a theory which was to prove disastrous in the years ahead. Newspapers in eastern towns and cities published glowing accounts of this region. It was a land where men and their families had only to reach to become economically free and independent.

Consequently, people came-immigrants, soldiers, missionaries, and fortune seekers.

In 1835, President Jackson sent 
William A. Slacum on a mission of inquiry into Oregon Territory. Mr. Slacum considered the Willamette Valley of Oregon the finest grazing country in the world. He assisted in transporting men from the Willamette Valley by ship to California to purchase and drive a herd of cattle back to Oregon. This was in January 1837. Late that summer the men returned with nearly 800 head of cattle.

Two years later a committee of the Hudsons Bay Company established the Puget Sound Agricultural Company. It established extensive farms at Nisqually and Cowlitz in western Washington and imported cattle and sheep from California. The objective of the Company was to develop flocks and herds on an extensive scale to produce wool, hides, and tallow for the British market.

By 1850 , from small beginnings, herds were expanding throughout the Territory. Thousands of cattle were being driven across the plains to the Northwest. This region was on the eve of one of the most colorful, courageous, and finally, disappointing periods in American history. The day of the cattle king and the range baron, the day of exploitation of rangeland had arrived.

In 1860 there were 65,000 people in the new state of Oregon and the territory of Washington and nearly 200,000 cattle. Expansion in the use of rangeland had been fantastic.

Along with the growth of the cattle industry was the expansion of sheep raising. The Puget Sound Agricultural Company raised sheep on its Nisqually and Cowlitz farms. A few head were brought to the mission at Waiilatpu near Walla Walla, Washington, in 1841 from Hawaiian Islands. A flock of sheep was driven to the Willamette Valley in the wake of that first cattle drive from California in 1837. In 1844, the first sheep crossed the plains into Oregon.

Emphasis usually is placed on cattle and sheep as the consumers and destroyers of grass, but it must be remembered that horses also increased in great numbers. Everyone needed horses. In addition to those raised and used, there were thousands of wild horses on the range. This explosive expansion of livestock on the open range was soon to take its toll, but up to this time it was barely noticeable.

The oldtime cattleman, the rangeland operator of 1850-1890, was probably the toughest, most courageous, most independent, sometimes the kindest, and often the ornriest character this country ever produced. From where we are now, he appears to have been in some respects a man of vision and in others a man without foresight. The normal risks he accepted as part of his business would appear overwhelming to most people today. Let's look at some of the facts of life that faced him. First, he had to acquire a few head of cattle and get them to the open range. Then his troubles really began. To name a few, there were marauding Indians; rustlers (other men trying this method of getting a start for themselves); natural predators such as coyotes, wolves and cougars; poison weeds and roots which cattle often ate; rattlesnakes; natural disease; grass and forest fires; and bitter cold winters. These things the cattleman accepted, fought, and finally overcame. His real fight for existence was yet to come.

Despite these hazards, the cattle industry boomed. These were the days when the cattleman was king, the day of the cattle drive, the cow town and the cowboy-a colorful and interesting period.

Even in 1850, cattlemen were striving to improve the quality of their livestock. Purebred cattle, sheep, and horses were brought to the region.

Until about 1870, all the products of the expanding cattle and sheep industry were utilized locally. Mining operations were extensive and thousands of miners throughout the Northwest required meat and other products. The booming Cariboo district in British Colum- bia was one of the most notable markets for livestock. Soon after the discovery of gold in this region, miners came by the shipload from California to Victoria, then moved inland to the gold fields. In the summer of 1858, General Joel Palmer organized a cattle drive at Fort Okanogan in Washington Territory. This drive moved up the Okanogan River, across into British Columbia south of Osoyoos, and then to the vicinity of Kamloops, where the miners happily welcomed the General and his herd.

Later, one of the great cattle kings of the Northwest, Ben Snipes, drove herds from the Yakima Valley to the Cariboo mining area. Some cattle were even driven from Oregon to this lucrative market. Local men in British Columbia soon recognized the possibility of raising cattle for this market on their own rangelands and, thus, the cattle industry in British Columbia was born.

The contribution of the Northwest to the early expanding cattle business of the Great Plains has been given scant notice. Cattle drives from Texas and the Southwest have been highly popularized by writers whereas the role of the Northwest, although prominent, has been neglected. It is important to the history of the great American West to recognize the contribution made by the cattle industry of the Pacific Northwest.

During the 1840's and 1850's, cattle multiplied rapidly in the Pacific Northwest, particularly in western Oregon. With the increase of mining in eastern British Columbia, Washington, and Oregon during 1858, a rush of people moved eastward and soon the Columbia Basin was swarming with people. This created a huge demand for food. To satisfy this demand, cattlemen began moving their herds from western Oregon into the Columbia Basin during the 1860's and even later. So rapid was this expansion that by the early 1870's cattlemen of the Pacific Northwest were facing a depression because 
their markets were glutted. At the beginning of 1872 the average price in Oregon for oxen and other cattle was $\$ 23.23$ per head. In January 1877 it was $\$ 11.80$. Prices remained low until 1880 when there was a slight increase which continued for about 5 years. This depressed price in Oregon was similar to that for the United States during the late 1870's.

Relief came to these hard-pressed cattlemen from increasing contacts made with markets east of the Rocky Mountains where there was a growing demand for cattle (Oliphant, 1946). In 1875 it was reported that hundreds of cattle were bought at Walla Walla, Washington, and driven to the Wyoming Territory. This started a slight movement of cattle eastward from the Northwest. Year by year this movement increased after an effective beginning in 1876 . One buyer's herd in 1877 reportedly numbered 16,000 head and there were other cattle buyers moving cattle eastward each year. Because of their quality, a large proportion of these cattle was being used to build base herds east of the Rocky Mountains.

The movement of cattle eastward from Oregon country reached its peak in 1880 . It was estimated that about 200,000 head had moved eastward from the Pacific Northwest that year. The winter of 1880-81 decimated herds throughout the Northwest but numbers built up again so that in 1882 a large number of livestock, including sheep and horses, were trailed eastward. The drive in 1882 was the last important one to be made from Oregon country because the great surplus of cattle had been moved out of this region. With the completion of the Northern Pacific Railroad in 1883, trailing livestock out of the far Northwest diminished and shipping by rail increased. A rail shipment of Oregon cattle was made from Winnemucca, Nev., to Chicago as early as 1878 , and in 1879 shipments to feeding grounds in Nebraska and Iowa were recorded. By 1885, the Utah and
Northern Railroad and the Oregon Short Line also were providing a market outlet.

It is noteworthy that the cattle from the Northwest were considered by the Wyoming buyers to be superior to Texas cattle as a base upon which to build their herds. Before 1876 or 1878 the great bulk of cattle were brought to that area from Texas. After that, their cattle came from the Northwest, Nevada, Utah, and Idaho until it was reported that they had "practically exhausted the supply of Nevada, Oregon and Washington Territory."

During this period of grazing on the open range, there was no such thing as ownership of land, except that the Indians actually owned all of it. It is true that cattle and sheep men often established a place as their general headquarters or home range, but livestock grazed without much control. A large cattle owner might consider that a certain general area, extending perhaps 50 to 100 miles or even more from his home range, was his range although he had no legal claim to the land. Under this method of management, cattle from two or more owners often mingled on the same range. A method of branding and marking the calves was established, but often a cattleman did not know, even at roundup time, how many cattle were actually his.

Carlson (1940) reported that in 1865, a Mr. F. Fry, an early eastern Washington settler, said "The most of which (eastern Washington) is spread over with rich succulent grass, forming one of those grand natural pastures, whereon innumerable herds of cattle might be raised with very little attention, the climate being so mild as to allow their running at large during the winter-the grass matures in the early part of the season and cures while standing on the ground, making winter as well as summer pastureno part of America is better adapted to the growing of wool and sheep."

Mr. Fry certainly was correct about the grand and natural pas- ture. His statement about the need for little attention to the livestock was generally accepted throughout the region. One newspaper of that time stated that a steer worth $\$ 5$ at birth was worth $\$ 45$ after four or five years on the open range. This was sometimes true provided of course the steer was still around at the end of 4 or 5 years.

One of the hazards that caught up with the stockmen several times from 1850 to 1890 was the climate, which was anything but mild. It was commonly believed that there was no need to raise hay and store it for winter usc because winters in the Northwest were such that livestock could take care of themselves out in the open. Dry grass was available under the snow or sticking through it; temperatures were such that animals could live through winter in comparative comfort.

Despite the warnings of the winter of 1847-48, cattlemen believed in the yearlong open-range idea, and they were fairly correct until the winter of 1861-62. Snow came early, it piled deep, temperatures fell to more than 30 degrees below zero in nearly all areas east of the Cascades. It stayed that way for weeks. Later a warm spell was followed by more subzero weather which caused a crust on the snow so hard that no animal could break through to find feed. Through starvation and exposure to subzero temperatures, cattle and sheep died by the thousands. Some large owners were wiped out completely. The range was a graveyard in the spring of 1862. A Walla Walla newspaper stated that a thousand yards from town, one could almost step from one dead cow to another throughout the whole valley.

This was a catastrophe for stockmen, an almost unbelievable blow to the industry. But these men were tough and courageous. The cattle industry came back and it came back strong, but strangely enough, very few people believed yet that shelter should be provided for livestock in winter. Very few be- 
lieved that it was necessary to provide supplemental feed. One rancher in the Yakima Valley of Washington put up stacks of hay in the middle 1860's and did not use any of it during a 5 year period.

So the open range idea prevailed and was generally again successful until the winter of $1880-81$, which was like the terrible winter nearly 20 years before. Although the industry again suffered a devasting blow, it again came back and, as previously stated, the 1880's were some of the finest years for Northwest cattlemen. The cold waited for nearly nine years before it struck again. After the still-remembered winter of 1889-90, most cattlemen finally accepted the fact that shelter and feed were required for a good cattle operation.

When railroads came to the Northwest in the 1880's, they provided something new to stockmen. Here was something that opened up new vistas, new markets, and new opportunities. A statement in the Journal, Bismarck, No. Dak., announced that the Northern $\mathrm{Pa}$ cific Railroad had contracted to bring 40,000 head of cattle from Washington Territory. The major market, however, continued to be Chicago. A peak price of $\$ 9.35$ per hundred pounds was reached in 1882.

Things must have appeared rather rosey to cattlemen and sheepmen in the Northwest at that time. Local markets were increasing by virtue of a growing population. Foreign markets were improving, and now they had direct transportation to the beef-hungry cities of America. They were seeing the brilliant sunset just prior to the night. Already some shadows were falling.

Here and there were complaints about deterioration of the range. Soil erosion was being noted. Cattle were not doing as well in certain areas as previously. By 1885 , two points were clear. First, cattle raising was no longer a frontier industry. Secondly, it was a victim of overexpansion. This overexpan- sion was notable at that time in Washington, Oregon, Idaho, and probably to a lesser degree in British Columbia.

The greatest blow to believers of the open-range concept was beginning to be felt-a blow to be delivered by those who believed in private ownership of land.

It must be remembered that up to this time there were few barriers that could actually prevent movement of cattle. While rivers slowed the progress of cattle, they could be crossed by swimming. Large herds often crossed from one shore of the Columbia River to the other. Large herds also were driven through mountain passes from one river basin to another. Through all of this, they had right-of-way. To obtain right-of-way across private property is often more difficult than overcoming physical obstacles.

The stockman of the open range was one of the first major users of a natural resource in the Northwest. He helped build and develop the country. He was generally a good citizen. Naturally, he felt that his way of life was good and that the open range was his. True, he and his cattle, sheep, and horses had taken it from the Indians and their horses, but he intended to keep it.

A new kind of immigrant was moving into the Northwest-people who wanted to own 160 acres to plow, plant, and harvest, to stay put and live at home. The Federal Homestead Act of 1863 gave these people the opportunity to select a homestead, improve it, and own it. As they moved in, land was fenced with barbed wire, water holes and streams were fenced from use by stock on the open range; plows turned grassland under to produce wheat, hay, and vegetables.

Railroads also took their chunk of rangeland. In order to induce and assist railroads to build into the Northwest, the Government made grants of land to railroad companies. In some cases, a company was granted every odd-numbered section (a square mile con- taining about 640 acres) of land for 10 miles on each side of the right-of-way. One company received every odd-numbered section for 20 miles on each side of its right-ofway in states and 40 miles on each side in territories. For a number of years, such companies allowed these sections to be used as open range, but as it became evident that overgrazing was doing damage and that these lands could be leased or sold, they were gradually removed from the open range.

As time and experience progressed, more and more was learned about grazing management. Certainly, cattlemen from Texas and the Southwest had previously seen what overgrazing had done in those arcas. But cvery area of rangeland has its own characteristics. On the fringe of the grasslands of the Northwest grew a rugged shrub called sagebrush (Artemisia tridentata Nutt.). Throughout the centuries bunchgrass had conquered its own domain, but always at hand, sometimes in rocky or shallow soil or other droughty situations, but sprinkled throughout the grassland area was the ever-present sagebrush. As soon as bunchgrass gave an inch, either through overgrazing, fire, drought or erosion, sagebrush moved in. After years of such treatment, where grass had dominated the land, sagebrush had taken over. As more people occupied the area, grass and forest fires became increasingly prevalent. It seems to be a way of nature in much of the Northwest for cheatgrass (Bromus tectorum L.) and rabbitbrush (Chrysothamnus $\mathrm{spp}$ ) to take over the soil after bunchgrasses have been burned severely. Another plague that occasionally hit the rangeland was grasshoppers. In some districts they appeared in such hordes that they consumed every blade of grass. All this reduced the stockmen's grazing resources.

As the demand for rangeland increased, men became more conscious of their individual rights and ambitions. Cattlemen fought each other for rangeland and 
waterholes, but most of their concern and hatred was directed towards sheep. From 1870 until the Government assumed some control of grazing lands, there was constant friction between cattlemen and sheepmen. Cattlemen maintained that sheep with their small hoofs stamped out grass and that the scent of sheep was repugnant to cattle and horses.

Following the unusually severe winter of 1889-90 and hard times of 1893, sheep began to increase rapidly. In 1892 sheep in great numbers moved into eastern Oregon and across the Columbia River into Washington (Carlson 1940).

Sheep could be fed and cared for on the range at a far smaller expense than cattle. Times were hard so the sheep were left to multiply until an acceptable market was ready. Roving bands of sheep crossing the ranges of cattlemen, often before the range was ready to use and on ranges already overstocked, led to the belief that sheep were the chief cause of range deterioration.

Roving bands of sheep on already overstocked ranges led to range wars in the 1900's. These wars chiefly centered in Crook, Lake, Wheeler and Deschutes counties in south central Oregon. The Sheep Shooter's Committee of Crook County claimed to have killed eight to ten thousand sheep a season for several years. On February 3, 1904, at Christmas Lake, Lake County, Oregon, 2,500 sheep were killed; and the remainder of a band of 3,000 were scattered. On January 1, 1905, 500 sheep were killed in Crook County.

Occasionally a sheepherder was killed. More often they were tied up and turned loose after their band was killed and scattered, with a warning not to come back. Reprisals by sheepmen were frequent. The Winchester ruled the range. Except for local outbursts, this open-range war ended in April 1906 when the U.S. Forest Service began to allot separate ranges to cattle and sheepmen. By this time,

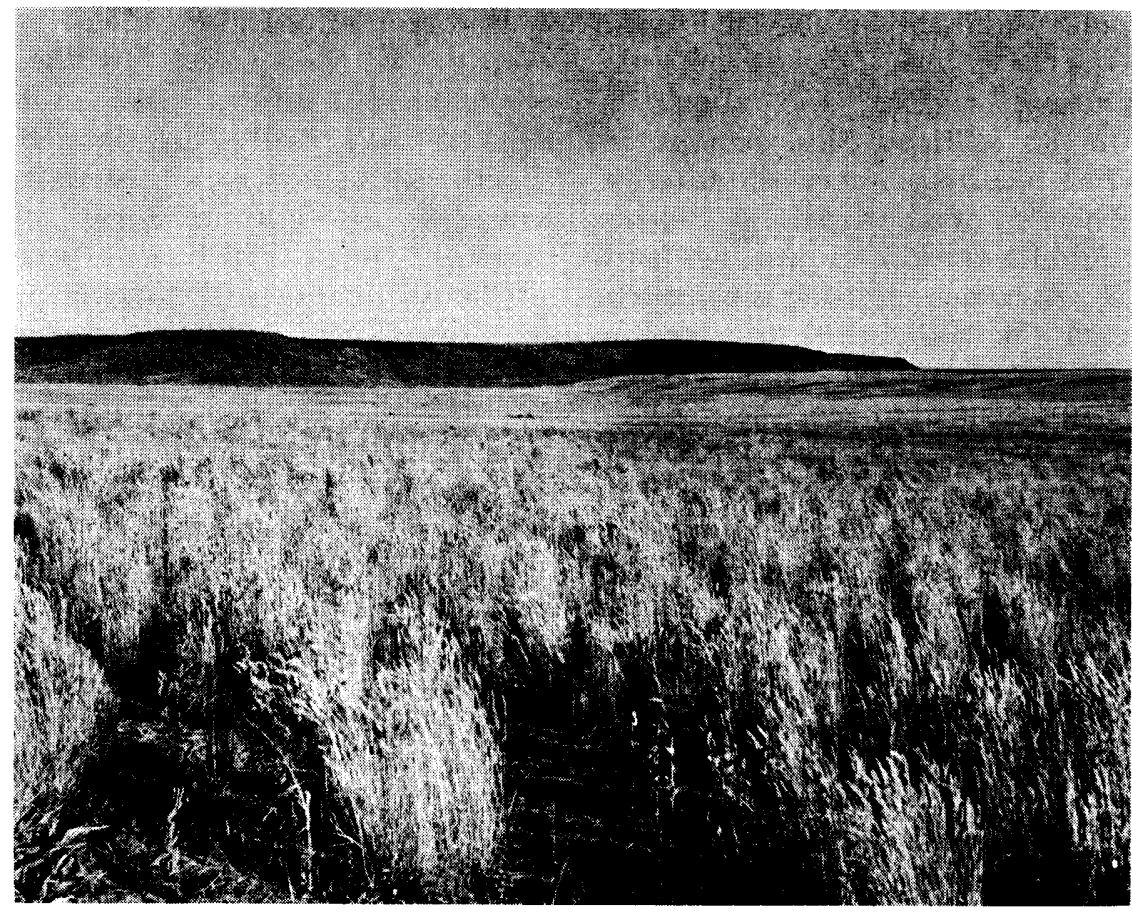

Fic. 2. An extensive range seeding on land too depleted for native species to recover within a reasonable time through resource management alone. (Bureau of Land Management photo)

conflicts of interest werc so many and so complex that controls were necessary and inevitable.

The first real move on the part of the Federal Government to control grazing was through creation of Forest Reserves in 1897. These were established under the Department of Interior where they remained until 1905 when the Forest Service was set up in the Department of Agriculture. By granting grazing permits, the Forest Service was able to limit the number of livestock on a given area and also limit the time that the range could be used. This reduced livestock on the range somewhat but gave more security to those who remained. Effective grazing laws were developed and put into effect in $\mathrm{Na}$ tional Forests in 1910.

The World War I period has its effect on the range livestock industry. In their endeavor to raise more wheat, ranchers broke new ground and plowed native pastures. Large acreages were taken from native grasslands. The price of cattle and sheep increased. It appeared that prosperity was here.
Good times that followed promoted a feeling of animosity toward the control of rangeland grazing. The depression of the 1930's, the country-wide drought, and the visible destruction of the range, however, brought about a change in attitudes. By the middle 1930's the public was ready for controls.

In 1933, the Soil Erosion Service was established in the Department of Interior. It was transferred to the Department of Agriculture in 1935 and renamed the Soil Conservation Service. Following a period of conservation demonstrations, soil conservation districts were gradually cstablished under state laws and with local leadership. These districts included farmland, rangeland, woodland, and watersheds. Farmers and stockmen became cooperators in making long-range plans for conservation use, development and management of their range and related resources with technical help from the Soil Conservation Service.

In 1934, Congress passed the Taylor Grazing Act which placed administration of unappropriated 
public lands under the Division of Grazing, which later became the Grazing Service and then the Bureau of Land Management under the Department of Interior. This Act read in part as follows: "Administration of grazing lands .... insofar as grazing is consistent with the withdrawal . . and to regulate occupancy and use of grazing land: to preserve the land and its resources from destruction or unnecessary injury, to provide for the orderly use, improvement and development of the range; and to continue study of erosion and flood control, and to perform such work as may be necessary to amply protect and rehabilitate the range." This was one of the major laws passed by Congress in the interest of range rehabilitation and development (Fig. 2).

During World War II most of the regulatory and conservation agencies carried on although with limited manpower. Their continued activity helped prevent unwise use and exploitation such as had developed during World War I. Since the middle 1940's, Federal, state, and local conservation and development agencies truly have become effective. State universities and experiment stations have contributed much to research, education, resource planning and development. Farmers, ranchers, and urban people have increased their participation in the conservation movement. The public has shared the cost of conserving the Northwest's resources through the Agricultural Conservation and Stabilization Service.

In British Columbia, there was no active control of grazing on public lands until 1919 when the Grazing Act was passed. By then the preferred ranges were overstocked and badly deteriorated. These problems were partially solved by opening up some less accessible lands which had been previously untouched. Grazing on all Crown lands, whether included in a provincial forest or not, is administered by the B.C. Forest Service under provisions of the Grazing Act. This is carried on by the Province rather than the Dominion Government. In this respect the British Columbia Forest Service performs the combined functions of the U.S. Forest Service and the Bureau of Land Management. Assistance in rangeland conservation to private land owners has been provided primarily by research workers and, only recently, by an extension range specialist.

In conclusion it may be said that at first there was the land, the grass, and the water. As time went on, rangelands became overgrazed, the forage dwindled because of conflicts of interest and overexpansion of the livestock industry. To satisfy the many interests and to rehabilitate the range and promote good conservation practices, Federal, state, and private administration, planning, development, and management became a necessity. Under public administration of these laws and through cooperation between stockmen, other users, and administrative agencies, livestock grazing on rangelands in the Pacific Northwest will continue to be one of the strong basic industries in the economy of the region. There are many millions of acres of private and public rangeland and grazable woodland in the Pacific Northwest on which concurrent grazing of livestock and wildlife should continue to be one of the major uses made of the resource.

\section{Selected References}

Boyce, T. V. 1937. A history of the beef cattle industry in the Inland Empire. Thesis on file, Wash. State Univ., Pullman.

Briggs, H. E. 1934. The development and decline of open range ranching in the Northwest. Mississippi Valley IIist. Review 20:521536.

Briggs, H. E. 1937. The early development of sheep ranching in the Northwest. Agr. History 2(3).

Carlson, N. K. 1940. The history of grazing and livestock development in the Pacific Northwest. U.S. Dep. Agr., Soil Conserv. Serv. Mimeo $19 \mathrm{p}$.

Haines, Francis. 1938. The northward spread of the horse among the plains Indians. Amer. Anthropol. July-Sept.

Haines, Francis. 1938. Where did the plains Indians get their horses? Amer. Anthropol. Jan-March.

Kingston, C. S. 1923. Introduction of cattle in the Pacific Northwest. Wash. Hist. Quart. 14:163-185.

Oliphant, J. ORIN. 1932. Winter losses of cattle in the Oregon country. Wash. Hist. Quart. 23:13-14.

Oliphant, J. Orin. 1933. The cattle trade on Puget Sound, 1858-1890. Agr. Hist. 7:129-149.

Oliphant, J. Orin. 1933. A beefcanning enterprise in Oregon. Oreg. Hist. Quart. 34:241-254.

Oi.iphant, J. Orin. 1946. The eastward movement of cattle from the Oregon country. Agr. Hist. 20: 1943.

Osgood, E. O. 1929. The cattlemen in the agricultural history of the Northwest. Agr. Hist. 3:117-130.

1971 Summer Meeting

July 29-31

A meeting for all members of the family-outdoor camping or indoor lodging. Visit Mt. Rushmore, the Black Hills, the Badlands. Program details in a future issue. 